УДК 125.7/9:316.4.063.34

Щербіна Ольга Сергіївна, кандидат економічних наук, доцент, доцент кафедри інформаційних систем управління Донецького національного університету імені Василя Стуса o.shcherbina@donnu.edu.ua ORCID 0000-0001-5029-6098

Шевчук Олеся Сергї̈вна, магістрант кафедри інформаційних систем управління Донецького національного університету імені Василя Стуса shevchuk.olesya@donnu.edu.ua ORCID 0000-0003-1607-6176

\title{
КООПЕРАЦІЯ БІБЛІОТЕК УКРАЇНИ В НАПРЯМІ ЗБЕРЕЖЕННЯ НАЦІОНАЛЬНОЇ ДОКУМЕНТАЛЬНОЇ СПАДЩИНИ
}

Мета роботи - визначити напрями кооперачії бібліотек України в аспекті збереження національної документальної спадщиини. Методологія. Дослідження базується на структурнофункиіональному підході щодо аналізу бібліотечних фондів та колекцій; під час узагальнення матеріалу використані загальнонаукові методи: індукиія, дедукиія, аналіз, синтез. Наукова новизна роботи полягає в обтрунтуванні необхідності кооперації бібліотек України в напрямі збереження начіональної документальної спадщини. Висновки. Забезпечення збереження фондів належить до основних функиій будь-якої публічної бібліотеки. Для иього бібліотека потребує відповідно обладнаних книгосховищ, технічного устаткування, кваліфікованих кадрів, відповідного фінансування та нормативної бази. Однак в Україні протягом багатьох років більшість із названих передумов належного збереження бібліотечних фондів були явно недостатніми, через що частка зномених документів у бібліотечних фондах постійно зростає, а поповнення новими виданнями є надто незначним; умови багатьох книгосховищ є невідповідними, бракує фахівців, обладнання, сучасних технологій збереження та реставраиії бібліотечних документів. 3метою посилення відповідальності за збереження стародруків, рідкісних і цінних видань фахівиі розробляють та запроваджують у практику короткий паспорт, який складається до кожного видання. Він вміщує мінімум необхідних бібліотечно-бібліографічних відомостей про книги та часописи, тому він зветься коротким. Заповнений паспорт приклеюється на початку чи в кінці документа на звороті обкладинки. Кооперація бібліотек потрібна не тільки для того щоб зафіксувати видання в иифровому депозитарії чи виготовити циифрову копію як страхову, але й для дистантного обслуговування користувачів, тому доцільно враховувати наявні (виставлені) ресурси інших установ.

Ключові слова: бібліотечний фонд, пам'ятки, бібліотеки, національна документальна спадщина, національна культурна спадщина, кооперація, збереження.

Щербина Ольга Сергеевна, кандидат экономических наук, доцент, доцент кафедры информационных систем управления Донецкого национального университета имени Васыля Стуса

Шевчук Олеся Серхї̈вна, магистрант кафедры информационных систем управления Донецкого национального университета имени Васыля Стуса

\section{КООПЕРАЦИЯ БИБЛИОТЕК УКРАИНЫ В НАПРАВЛЕНИИ СОХРАНЕНИЯ НАЦИОНАЛЬНОГО ДОКУМЕНТАЛЬНОГО НАСЛЕДИЯ}

Цель работы - определить направления кооперации библиотек Украины в аспекте сохранения национального документального наследия. Методология. Исследование базируется на структурнофункииональном подходе к анализу библиотечных фондов и коллекций; во время обобщения материала

(C) Щербіна O.C., Шевчук О.С. 
использованы общенаучные методы: индукция, дедукция, анализ, синтез. Научная новизна работы заключается в обосновании необходимости кооперации библиотек Украины в направлении сохранения начионального документального наследия. Выводы. Обеспечение сохранности фондов принадлежит к основным функциям любой публичной библиотеки. Для этого библиотека требует соответственно оборудованных книгохранилищ, технического оборудования, квалифицированных кадров, соответствующего финансирования и нормативной базы. Однако в Украине на протяжении многих лет большинство из названных предпосылок надлежащего сохранения библиотечных фондов были явно недостаточными, вследствие чего доля изноченных документов в библиотечных фондах постоянно растет, а пополнение новыми изданиями незначительно; условия многих книгохранилищ, является неподходящими, не хватает специалистов, оборудования, современных технологий сохранения и реставраџии библиотечных документов. С иелью усиления ответственности за сохранение старинных, редких и ценных изданий специалисты разрабатывают и внедряют в практику короткий паспорт, который составляется к каждому изданию. Он вмещает минимум необходимых библиотечно-библиографических сведений о книгах и журналах, поэтому он называется коротким. Заполненный паспорт приклеивается в начале или в конще документа на обороте обложки. Кооперация библиотек нужна не только для того чтобы зафиксировать издания в иифровом депозитарии или изготовить цифровую копию как страховую, но и для дистантного обслуживания пользователей, поэтому целесообразно учитывать имеющиеся (выставленные) ресурсы других учреждений.

Ключевые слова: библиотечный фонд, памятки, библиотеки, национальное документальное наследие, национальное культурное наследие, кооперация, сохранение.

Shcherbina Olha,

Candidate of Economic Sciences, Docent, Associate Professor at the Department of Information Systems of Management, Vasyl' Stus Donetsk National University

Shevchuk Olesia, Master Student at the Department of Information Systems of Management, Vasyl' Stus Donetsk National University

\section{COOPERATION OF LIBRARIES OF UKRAINE IN THE DIRECTION OF PRESERVATION OF THE NATIONAL DOCUMENTARY HERITAGE}

Purpose of Article is to determine the directions of cooperation of Ukrainian libraries in the aspect of preserving national documentary heritage. Methodology. The study is based on a structurally functional approach to the analysis of library collections and collections; general scientific methods were used during the generalization of the material as induction, deduction, analysis, synthesis. Scientific Novelty. The scientific novelty of the work is to justify the need for cooperation of Ukrainian libraries in the direction of preserving the national documentary heritage. Conclusions. Ensuring the safety of funds belongs to the main functions of any public library. For this, the library requires appropriately equipped book depositories, technical equipment, qualified personnel, appropriate funding, and a regulatory framework. However, in Ukraine over the years, most of these prerequisites for the proper preservation of library collections were clearly insufficient, as a result of which the proportion of worn-out documents in library collections is constantly growing, and replenishment with new editions is insignificant; the conditions of many book depositories are inappropriate; there are not enough specialists, equipment, modern technologies for preserving and restoring library documents. In order to strengthen responsibility for the preservation of ancient, rare, and valuable publications, experts develop and put into practice a short passport, which is compiled for each publication. It contains the minimum necessary library and bibliographic information about books and magazines, so it is called short. The completed passport is glued at the beginning or at the end of the document on the back of the cover. The cooperation of libraries is necessary not only to fix publications in a digital depository or to make a digital copy as an insurance one but also to provide distant services to users, therefore it is advisable to take into account the available (exposed) resources of other institutions.

Key words: library fund, memos, libraries, national documentary heritage, national cultural heritage, cooperation, preservation. 
Актуальність теми дослідження. Розвиток української культури, конкурентоздатність країни у світі сьогодні безпосередньо залежать від рівня освіти населення, кількості висококваліфікованих фахівців у різних сферах діяльності. Необхідну базу для цього формує система освіти, науки, мережа інформаційних центрів, зокрема, бібліотеки. Тому до стратегічних пріоритетів у гуманітарній політиці держави має належати забезпечення широкого доступу населення до різноманітної інформації, iï ефективного використання в процесі формування соціального капіталу. Однією із ключових передумов реалізації цього пріоритету $є$ збереження накопичених бібліотечних фондів [1, с. 50].

Якщо проаналізувати еволюцію співробітництва бібліотек, то можна сказати, що сьогодні жодна 3 них не може функціонувати ізольовано. Бібліотеки можуть ефективно виконувати свої функції тільки на основі кооперації, а інтенсивний розвиток технологій останніх років дає можливість кооперації ресурсів і обслуговування у небачених масштабах $[2$, c. 4].

Мета дослідження - визначити напрями кооперації бібліотек України в аспекті збереження національної документальної спадщини.

Аналіз досліджень і публікацій. Цінні наукові висновки стосовно діяльності бібліотечних установ і розвитку бібліотечної справи, зроблені такими вченими, як В. Горовий, М. Дворкіна, В. Ільганаєва, В. Мінкіна, О. Онищенко, М. Слободяник, А. Соколов, Ю. Столяров, тощо. Бібліотечні фонди та колекції як складову національної культурної спадщини досліджували: Г. Кисловська, О. Клименко, Г. Ковальчук, I. Крупський, Л. Лисятников, I. Лосієвський, Л. Сніцарчук та інші науковці України, які зробили вагомий внесок у бібліотекознавчий напрям.

Виклад основного матеріалу. Сьогодні збереження бібліотечних фондів - це глобальна проблема, від вирішення якої залежить, чи зможемо ми передати нащадкам спадщину минулих поколінь. Вона ускладняється тим, що за своїм призначенням бібліотеки повинні надавати можливість користуватися документами і одночасно дбати про їхнє збереження. Особливо актуальним це питання є для старо- друків і рідкісних видань, вивчення яких сприяє відновленню історичної пам'яті, ліквідації білих плям в історії нашого народу.

Організація роботи зі збереження цих фондів передбачає розв'язання цілого комплексу проблем: формування, опрацювання, забезпечення фізичного збереження та використання. Останнім часом дослідники приділяють все більше уваги питанням паспортизації історико-культурних фондів [3, с. 3].

Теорія та практика колекційного зберігання стародруків переконують, що для чіткого та всебічного обліку зібрань стародрукованих видань, окрім звичайного сумарного та індивідуального, потрібна паспортизація таких колекцій. Адже відомо, що значна частина стародруків дійшла до нашого часу в конволютах - штучних збірниках, які складаються 3 різних видань або рукописів. Конволюти трапляються видавничі, але найчастіше - власницькі: оскільки більшість видань виходили 3 друкарень без палітурок, власник добирав декілька, як правило, одноформатних книжок [4, c. 128].

Як відомо, велике значення для збереження книжкових пам'яток під час обслуговування користувачів має заміна оригіналів копіями. Виготовлення копій, принаймні найцінніших, рукописних книг і стародруків повинно бути постійним завданням у спеціалізованих історико-культурних відділах бібліотек. Наявність копій на бібліотечні примірники, також повинна бути представлена в паспорті.

Коли говорять про збереження культурної спадщини в бібліотеках, мають на увазі те, що сьогодні називають «книжковими пам'ятками». В багатьох нормативних документах і методичних рекомендаціях зафіксовано, що фондоутримувачі зобов'язані займатися консервацією книжкових пам'яток, котра забезпечуватиме їхню збереженість. Причому не тільки, так би мовити, фізичною консервацією, але й переведенням інформації, що міститься в книзі, іiї оформлення на нові носії - цифрові, а також задоволення ними потреб користувачів і вилучення оригіналів 3 активного обігу. За умови залишкового принципу фінансування бібліотек, кожна установа намагається вирішити ці питання самостійно. I часто трапляється так, що, шукаючи потріб- 
ний ресурс в Інтернеті, користувач знаходить кілька копій примірників одного видання на різних сайтах та не знаходить жодної копії інших видань.

Сьогодні відомо, чим саме займаються працівники з різних бібліотек, які пріоритети вони обрали для оцифрування документальної спадщини, що планують оцифрувати, а що вже оцифрували. Звідси випливає об'єктивна потреба у зведенні такої інформації. Це один iз напрямів можливої кооперації. Слід погодитися, що при недостатніх технічних, фінансових ресурсах витрачати час і ресурси на одні й ті самі видання не раціонально. Адже сьогодні не поставлено завдання суцільного оцифрування всіх бібліотечних фондів країни $[5$, c. 9$]$.

Якщо певні зразки книжкової спадщини оцифровуються в бібліотеках з метою не лише зафіксувати видання в цифровому депозитарії чи виготовити цифрову копію як страхову, але й для дистантного обслуговування користувачів, то доцільно враховувати наявні (виставлені) ресурси інших установ. В тому випадку, якщо створюється страховий фонд на власні раритети - тоді, безперечно, важливо зафіксувати особливості конкретного примірника. Таким чином, потрібна кооперація та координація роботи в цій галузі. Це $є$ актуальним і 3 позицій міжнародного представлення вітчизняних книжкових скарбів у світових електронних бібліотеках - таких, як Європейська чи Світова бібліотеки.

Тому перш ніж починати оцифрування будь-якого примірника, треба знати (перевіряти), хто вже має такий електронний ресурс, чи виставлений він on-line (це дуже важливо, оскільки більшість бібліотек надає доступ до електронних копій раритетів тільки в читальних залах, але з часом, слід сподіватися, що доступ до таких пам'яток, які належать людству, буде відкритий). I чи завжди ми взагалі знаємо, скільки і де в державі таких примірників (з україномовною книгою легше, $\epsilon$ друковані покажчики, але варто було б мати також зведену єдину електронну базу, що пришвидшило би пошук) [5, с. 10].

У безпосередньому зв'язку з цим інший напрям кооперації, пов'язаний зі створенням Державного реєстру національного культур- ного надбання (ДРНКН) у частині «Книжкові пам'ятки України».

Весь світ наразі працює в цьому напрямі, починаючи від програми ЮНЕСКО «Пам'ять світу», і багато країн мають свої реєстри книжкових чи навіть документальних пам'яток (на зразок «Пам'ять Америки», «Пам'ять Японії»); існують чи створюються Європейська бібліотека, Світова цифрова бібліотека, Консорціум європейських наукових бібліотек та ін. До речі, ЮНЕСКО час від часу нагадує країнам-членам цієї організації про необхідність створення національних реєстрів документальної пам'яті. Реєстр потрібен, насамперед, фондозберігувачам. Це джерело інформації для наукових досліджень, а також для правоохоронних органів, митниці, адже за Законом України «Про вивезення, ввезення та повернення культурних цінностей» [6], за межі держави не може бути вивезена пам'ятка, якщо вона занесена до Державного реєстру національного культурного надбання.

Під терміном «книжкові пам' ятки» закріплено: рукописні книги та друковані видання, які мають видатну духовну, матеріальну цінність, особливе історичне, наукове, культурне значення і відносно яких установлений особливий режим обліку, зберігання та використання. Дуже важливим є смисловий елемент, закладений у слові «установлений». Це означає, що видання може вважатися книжковою пам'яткою лише після експертної оцінки та реєстрації у спеціальному реєстрі книжкових пам'яток. Поки що всі підготовлені фондоутримувачами списки мають інформаційне значення, вони чи їхні певні позиції ще не затверджені в статусі книжкових пам'яток.

Отже, юридично це питання не відпрацьовано. Потрібен спеціальний закон, за яким ДРНКН набув би офіційного статусу обліковореєстраційної системи і реєстрація книжкових пам'яток стала б обов'язковою вимогою. Тоді на законодавчому рівні на всі бібліотеки, музеї і архіви буде покладено обов'язок своєчасно надавати відомості для реєстрації в ДРНКН книжкових пам'яток.

В Україні затверджено Порядок відбору рукописних книг, рідкісних і цінних видань до Державного реєстру національного культурного надбання. 
У роботі із забезпечення охорони і збереження книжкових пам'яток насамперед, необхідна сучасна законодавча база, котра однозначно диктуватиме обов'язки фондоутримувачів щодо створення загальнодержавного обліку рідкісних і цінних книг як вагомої частини національного надбання (у вигляді ДРНКН). Потрібен координатор цієї діяльності у вигляді хоча б невеликого структурного підрозділу. Функції такого окремого підрозділу, який був би науково-методичним і координаційним центром по роботі з книжковими пам'ятками, - створення нормативноправової бази, обгрунтування та популяризація науково-методичних питань, координація роботи, зведення даних від основних регіональних або галузевих центрів (бібліотек). Потрібні теоретичні напрацювання, обмін досвідом - він $є$ в багатьох установах.

Необхідно продумати і чітко розробити, затвердити на державному рівні весь ланцюжок - від опису конкретного видання в бібліотеці, експертизи і до його включення головною установою в цій справі до бази даних реєстру. Напрацьований на місцях у багатьох бібліотеках упродовж останніх років масив записів книжкових пам'яток потребує, нарешті, якогось зведення, узагальнення, оформлення в єдиний державний реєстр книжкових пам'яток.

Важливий напрям можливої кооперації в галузі збереження національного культурного надбання - це інформування один одного про кричущі випадки крадіжок книжкових пам'яток. Це не $\epsilon$ справою однієї бібліотеки, адже поки вона на свій розсуд розбирається 3 цією ситуацією, злочинець може прийти до іншої бібліотеки. За відсутності камер спостереження, повноцінної служби охорони, мікрочипів на книжках, хоча б на зразок охоронної системи книжкових магазинів, ми всі щоденно ризикуємо державним надбанням. Слід підкреслити, це не особиста справа постраждалої сторони, це проблема державного масштабу, яку важко технічно вирішити (перш за все з фінансових причин). I не тільки щодо конкретних прізвищ підозрюваних осіб, але й стосовно тематики книжок, що користуються наразі підвищеним попитом у злочинців, а також методів, якими користуються ці особи при скоєнні злочинів.
Наприклад, вирізають блоки книг із палітурок і на їхнє місце ювелірно вклеюють макулатуру, точно підрізану за форматом книжки; вирізають гравюри і виносять їх у папках 3 подвійним дном; по кілька разів виходять із читального залу, залишаючи начебто книжки на столі, свідомо та настійливо відволікають увагу чергових у залі, на контролі, а в результаті книжки зникають безслідно. Бібліотечні фахівці повинні обмінюватися відповідною інформацією, щоб не допускати подібних випадків, адже все, що зберігається в державних бібліотечних фондах, є національною культурною спадщиною [5, с. 11].

I ще один напрям діяльності з книжковим культурним надбанням. Принагідно слід підкреслити, що термін «національна культурна спадщина» чи, вужче, «національна документальна спадщина» в цьому контексті відноситься не лише до книжок україномовних або навіть створених на українських землях, але й до всіх книжкових скарбів, що зберігаються в державних фондах України. Проведення експертизи книг у бібліотеках, мета якої може бути різною:

邓 при купівлі книжкової пам'ятки бібліотекою і у випадку викрадення книжки;

\ при укладанні актів на тимчасове передавання раритету на експонування до іншої установи і при відборі книжкових пам'яток до ДРНКН;

\ при підготовці експертного висновку на книгу чи книги для Державної служби контролю за переміщенням культурних цінностей через державний кордон України або атрибуції дефектних примірників, у т. ч. для приватних осіб.

Слід наголосити, що існуючі методики проведення митної експертизи (Л. Калашникова), музейних цінностей (В. Індутного, Гемологічного центру), документів Національного архівного фонду України, антикварної оцінки не дуже підходять у даних випадках або підходять не повністю. Усвідомлена суспільством історико-культурна цінність книжкових пам'яток та їхня грошова вартість на світових аукціонах примушує працівників бібліотек впритул зайнятися цією справою і виробити спільні підходи щодо цього, на які можна спиратися, посилатися у випадку 
необхідності, тобто працювати більш-менш уніфіковано, злагоджено. Адже збереження національної книжкової спадщини - це справа, вагома й важлива. Отже, робота ця вкрай необхідна, довготривала і потребує державної підтримки. Програму потрібно продовжити, а корпоративну роботу бібліотек забезпечити фінансово у повному обсязі.

Наукова новизна роботи полягає в обгрунтуванні необхідності кооперації бібліотек України в напрямі збереження національної документальної спадщини.

Висновки. Забезпечення збереження фондів належить до основних функцій будьякої публічної бібліотеки. Для цього бібліотека потребує відповідно обладнаних книгосховищ, технічного устаткування, кваліфікованих кадрів, відповідного фінансування та нормативної бази.

Однак в Україні протягом багатьох років більшість із названих передумов належного збереження бібліотечних фондів були явно недостатніми, через що частка зношених доку- ментів у бібліотечних фондах постійно зростає, а поповнення новими виданнями $є$ надто незначним; умови багатьох книгосховищ $€$ невідповідними, бракує фахівців, обладнання, сучасних технологій збереження та реставрації бібліотечних документів.

3 метою посилення відповідальності за збереження стародруків, рідкісних і цінних видань фахівці розробляють та запроваджують у практику короткий паспорт, який складається до кожного видання. Він вміщує мінімум необхідних бібліотечно-бібліографічних відомостей про книги та часописи, тому він зветься коротким. Заповнений паспорт приклеюється на початку чи в кінці документа на звороті обкладинки.

Кооперація бібліотек потрібна не тільки для того щоб зафіксувати видання в цифровому депозитарії чи виготовити цифрову копію як страхову, але й для дистантного обслуговування користувачів, тому доцільно враховувати наявні (виставлені) ресурси інших установ.

\section{Список використаних джерел}

1. Горбань Ю. І. «Оцифрування» як сучасна технологія зберігання книжкових пам’яток у бібліотека. URL: http://www.nbuv.gov.ua

2. Вилегжаніна Т. Кооперація бібліотек: проблеми і переваги: Бібліот. планета. 2016. № 1. С. 4-6.

3. Конвенція про охорону та заохочення розмаїття форм культурного самовираження: Міжнародний документ від 20.10.2005. URL: http://zakon3.rada.gov.ua

4. Конвенція про охорону нематеріальної культурної спадщини: Міжнародний документ від 17.10.2003. URL: http://zakon2.rada.gov.ua

5. Ковальчук Г. Діяльність бібліотек зі збереження національної документальної спадщини: проблеми кооперації: Бібл. планета. 2010. № 3. С. 9-11.

6. Закон України «Про вивезення, ввезення та повернення культурних цінностей». URL: https:// zakon.rada.gov.ua/laws/main/1068-14

7. Шевчук О.С., Щербіна О.С. Методологія визначення бібліотечного фонду як складової частини національної культурної спадщини: Збірник матеріалів IV Всеукраїнської наукової конференції «Інформаційні технології і системи в документознавчій сфері» за підсумками науково-дослідницької роботи студентів спеціальності «Інформаційна, бібліотечна та архівна справа» [ред. кол. Г. П. Лукаш, О. М. Анісімова, І. Г. Передерій та ін.] Вінниця: ДонНУ імені Василя Стуса, 2019. С. 96-99.

\section{References}

1. Ghorbanj Ju. I. "Digitization" as a modern technology for storing book memos in libraries. URL: http:// www.nbuv.gov.ua. [in Ukrainian].

2. Vyleghzhanina T. (2016).Library Cooperation: Problems and Benefits: Bibliot. planeta. 1. P. 4-6. [in Ukrainian].

3. Convention on the Protection and Promotion of the Diversity of Cultural Expressions: International Document (2005). Retrieved from: URL: http://zakon3.rada.gov.ua. [in Ukrainian].

4. Convention for the Safeguarding of the Intangible Cultural Heritage: International Document (2003). Retrieved from: URL: http://zakon2.rada.gov.ua. [in Ukrainian].

5. Kovaljchuk Gh. (2010). Activities of libraries for preserving the national documentary heritage: problems of cooperation: Bibl. planeta. 3. P. 9-11. [in Ukrainian]. 